\title{
Penerapan Statcounter sebagai Alat Monitoring Aktivitas Website Hibah Perguruan Tinggi Raharja
}

\author{
Statcounter Implementation as Website Activity Monitoring Tool of Hibah \\ Perguruan Tinggi Raharja
}

\author{
Indri Handayani ${ }^{1}$, Maulana Sani ${ }^{2}$, Dewi Ratna Sari ${ }^{3}$ \\ ${ }^{1}$ Teknik Informatika STIMIK Raharja, ${ }^{2,3}$ Sistem Informasi STIMIK Raharja, \\ E-mail: *11indri@raharja.info, ${ }^{2}$ maulanasani@raharja.info, ${ }^{3}$ dewi.ratnasari@raharja.info
}

\begin{abstract}
Abstrak
Tingkat aktivitas suatu website merupakan suatu hal yang sangat penting untuk dapat diukur terutama untuk website yang pada dasarnya dibuat dan dialokasikan untuk memberikan pelayanan dan informasi bagi pengunjungnya. Website Hibah Perguruan Tinggi Raharja, merupakan website yang dibuat dan alokasikan Perguruan Tinggi Raharja untuk melayani dan memberikan informasi bagi setiap pribadi Raharja perihal kepengurusan Hibah seperti perihal permohonan Hibah misalnya. Berbagai pengembangan dan pembaruan dilakukan oleh pengelolanya untuk dapat terus menyajikan informasi dan website yang menarik bagi pengunjung. Namun pada penerapannya pengelola belum dapat mengetahui secara tepat mengenai siklus aktivitas pengunjung website. Penggunaan suatu alat monitoring, dalam hal ini Statcounter dapat memberikan data dan informasi yang berkualitas terutama perihal data statistic kunjungan (visit). Pada penerapannya, data dan informasi ini dapat dijadikan bahan pertimbangan bagi pengelola website untuk melakukan pengembangan atau perubahan guna meningkatkan kualitas website Hibah Perguruan Tinggi Raharja sehingga pengelola dapat menyesuaikan website berdasarkan besar kecilnya tingkat aktivitas kunjungan yang diterima Statcounter. Selain itu penggunaan Statcounter juga dapat membantu pengelola dalam hal memonitoring aktivitas website secara detil karena pada dasarnya Statcounter juga menampilkan data dan informasi mengenai aktivitas setiap pengunjung secara rinci.
\end{abstract}

Kata Kunci - Website, Hibah Penelitian, Statcounter, Alat Monitoring, Visitorcounter

\section{Abstract}

The level of activity of a website is a very important thing to be measured, especially for websites that basically created and allocated to provide services and information for visitors. Website Higher Education Grant Prog, a website created and allocated Perguruan Tinggi Raharja to serve and provide for each Personal information concerning the management of the Grant Prog like Grants for example regarding the petition. Various development and updates are done by managers to continue serving informationand the website attractive for visitors. However, the application manager can not know exactly about the website visitor activity cycle. The use of a monitoring tool, in this case Statcounter to provide data and information quality, in particular regarding the traffic data (visit) that the application, data and information can be considered for the manager of the website to develop or change in order to improve the quality of Hibah Perguruan Tinggi Raharja website so managers can customize the website based on the amount of traffic they receive the level of activity Statcounter. And not only was the use Statcounter also can assist the manager in terms of monitoring the activities of the website in detail because basically Statcounter also displays data and information regarding each visitor activity in detail.

Keywords - Website, Research Grant, Statcounter, Monitoring Equipment, Visitor Counter 


\section{PENDAHULUAN}

Informasi merupakan suatu yang sangat dibutuhkan oleh manusia saat ini, tergantung dari bagaimana suatu informasi, sebuah keputusan dapat diambil dan tergantung dari bagaimana suatu informasi juga suatu permasalahan dapat dipecahkan. Perkembangan informasi tentunya tidak luput dari adanya perkembangan teknologi informasi saat ini yang jelas sudah sangat maju, berbagai informasi apapun itu, kapanpun dan dimanapun dapat diakses dengan mudah dengan bantuan teknologi informasi saat ini. Seiring dengan berkembangnya teknologi informasi saat ini juga berperan besar dalam meningkatkan laju perputaran informasi dikalangan masyarakat, yang tentunya dalam hal ini peran teknologi informasi sangat besar dalam menjawab permintaan masyarakat akan informasi yang cepat dan akurat.

Perkembangan teknologi tentunya tidak hanya memberikan dampak positif bagi masyarakat tapi juga bagi pihak-pihak yang menggunakannya salah satunya institusi pendidikan. Perguruan Tinggi Raharja merupakan salah satu institusi pendidikan yang menggunakan teknologi informasi sebagai alat bantu penyebaran informasi di dalam setiap aspek kegiatannya.

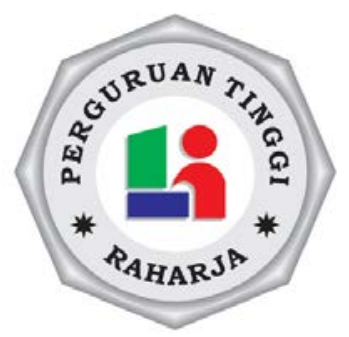

\section{Gambar 1. Logo Perguruan Tinggi Raharja}

Gambar 1 merupakan logo dari Perguruan Tinggi Raharja, sebagai salah satu Perguruan Tinggi yang bergerak dalam bidang Teknologi Informasi, Perguruan Tinggi Raharja memiliki keterikatan yang erat dengan laju perkembangan teknologi informasi dimana teknologi informasi banyak berperan dalam sistem perkuliahan yang dijalankan di Perguruan Tinggi Raharja, salah satunya sebagai alat bantu penyebaran informasi perkuliahan dan informasi-informasi lainnya.

Website Hibah Perguruan Tinggi Raharja, merupakan salah satu fasilitas pelayanan berbasis CMS Wordpress yang dibuat dan disediakan oleh Perguruan Tinggi Raharja, yang berperan sebagai penyedia informasi seputar Pemberian Hibah serta pengurusan pengajuan Hibah mulai dari request surat pengantar sampai dengan informasi seputar pedoman penulisan proposal Hibah kepada setiap Pribadi Raharja. CMS atau Content Management System adalah suatu metoda mengelola sebuah contentc/isi. Content bisa berupa teks, suara, gambar, video, animasi dan aplikasi lainnya yang disimpan dalam sebuah database sehingga, mudah dalam pengelolaannya [1].

Penyediaan fasilitas website Hibah Perguruan Tinggi Raharja ini tentunya merupakan hal yang sangat membantu bagi setiap Pribadi Raharja, terutama karena Hibah merupakan salah satu persyaratan dari kelulusan di Perguruan Tinggi Raharja. Sebagai salah satu fasilitas dari Perguruan Tinggi Raharja, Hibah Perguruan Tinggi Raharja harus dapat terus berkembang dan meningkat terutama dalam hal informasi, dimana Hibah Perguruan Tinggi Raharja harus dapat memberikan informasi yang update dan menarik bagi pengunjung agar dapat memberikan informasi yang berkualitas.

Oleh karena itu penerapan suatu alat monitoring yang dapat mempermudah Pengelola untuk dapat me-monitoring perkembangan website Hibah Perguruan Tinggi Raharja sangat dibutuhkan, dalam hal ini adalah visitor counter (sebelumnya menggunakan Flagcounter) dimana pada penerapannya visitor counter adalah alat yang dapat menampilkan angka kunjungan dimana hal itu dapat dijadikan alat monitoring terhadap tingkat aktivitas kunjungan pada website Hibah Perguruan Tinggi Raharja. 
Statcounter merupakan salah satu penyedia visitor counter yang dapat diakses secara gratis. Salah satu keuunggulan yang ada pada statcounter adalah angka visitor counter diambil berdasarkan unique visit. Berbeda dengan Flagcounter, sistem penghitungannya berdasarkan page-load atau banyaknya halaman dimuat. Selain itu, beberapa statistik lain yang dihasilkan Statcounter merupakan data dan informasi yang dapat dijadikan bahan pertimbangan berkualitas yang dapat dijadikan acuan untuk pengembangan website Hibah Perguruan Tinggi Raharja, sehingga dari segi perhitungan pengunjung Statcounter dapat memiliki nilai yang lebih baik.

\section{METODE PENELITIAN}

Metode penelitian yang diterapkan dalam penelitian ini adalah metode permodelan menggunakan Unified Modeling Language (UML) dan literature review, Unified Modeling Language (UML) adalah bahasa standar yang digunakan untuk menulis blueprint perangkat lunak. UML dapat digunakan untuk memvisualisasi, menspesifikasikan, membangun, dan mendokumentasikan artifak dari sistem perangkat lunak [2], dan pengumpulan data dengan teknik observasi, wawancara, serta studi pustaka. Observasi dilakukan secara langsung dengan memonitoring website Hibah Perguruan Tinggi Raharja secara rutin. Wawancara dilakukan dengan narasumber beberapa pengelola website saat ini, yang membahas peran visitor counter yang sebelumnya menggunakan Flagcounter, apakah dapat dijadikan bahan pertimbangan untuk pengambilan keputusan dalam rangka pengembangan dan peningkatan website Hibah Perguruan Tinggi Raharja. Kemudian setelah beberapa diterapkannya metode diatas dicari suatu alternatif pemecahan masalah kemudian implementasi atas alternative pemecahan masalah yang telah dipilih.

Kemudian dalam upaya peningkatan visitor count sebagai alat monitoring aktivitas website Hibah Perguruan Tinggi Raharja ini, beberapa literature review telah disiapkan diantaranya untuk mengidentifikasikan kesenjangan, menghindari pembuatan ulang, dan meneruskan penelitian sebelumnya. Beberapa literature review tersebut diantaranya adalah sebagai berikut:

1. Penelitian yang dilakukan oleh Ifadah Amalia dan Karmilasari dari Universitas Gunadarma, Depok pada tahun 2011 yang berjudul "Analisis Kepopuleran iMe UKM dengan metode Survey dan Perangkat Bantu SEO dan Trance Visitor”. Dimana dalam penelitian Mereka membahas tentang analisis kepopuleran pada iMe UKM dengan menggunakan metode survey kepada pengunjung iMe untuk memberikan penilaian secara kualitatif, serta pengamatan secara langsung dengan menggunakan alat bantu trace visitor dan penerapan SEO pada iMe UKM tersebut [3].

2. Penelitian yang dilakukan Julian Ross dari Department of Conservation pada tahun 2005 yang berjudul "Visitor counters in parks: management practice for counter calibration". Penelitian tersebut membahas tentang penerapan metode penghitungan akurat yang dapat membedakan berapa banyak angka pengunjung yang berjalan kaki dan berapa banyak yang menggunakan kendaraan. Tujuannya adalah untuk dapat memberikan data yang tepat serta meningkatkan kualitas data pengunjung yang dikumpulkan. Selain itu penerapan metode koreksi kesalahan yang dapat mengatasi permasalahan seperti perulangan penghitungan apabila ada pengunjung yang "keluar" dan "kembali” melalui rute yang sama, ataupun tidak terdeteksinya anak yang terlalu kecil oleh counter [4].

3. Penelitian yang dilakukan Gordon Cessford, Stuart Cockburn, dan Murray Douglas dari Science and Research Unit, Department of Conservation pada tahun 2002 yang berjudul “Developing New Visitor Counters and their Applications for Management”. Penelitian ini membahas tentang rancangan visitor counter yang digunakan untuk memperoleh data yang akurat dari lapangan dengan cara yang handal dan murah biaya dalam rangka membangun model arus pengunjung untuk mengelola pengunjung ke kawasan konservasi [5].

4. Penelitian yang dilakukan Gaurav Waradkar, dkk dalam Imperial Journal of Interdisciplinary Research (IJIR) Vol-2, Issue-4, tahun 2016 yang berjudul “Automated Room Light Controller 
with Visitor Counter”. Penelitian ini membahas tentang penggunaan visitor counter sebagai alat monitoring pengambilan keputusan untuk sistem penerangan otomatis pada ruangan. Dalam implementasinya sistem penerangan suatu ruangan akan bergantung dengan ada tidaknya orang (visitor) dalam ruangan. Namun pada kenyataannya tidak sesederhana itu, karena pada penelitiannya tingkat penerangan dan banyaknya penerangan yang aktif juga berdasarkan banyaknya orang (visitor) di ruangan, dan sebaliknya penerangan akan mati apabila orang (visitor) meninggalkan ruangan [6].

5. Penelitian yang dilakukan Jere Rauhala, Joel Erkkonen, dan Heikki Iisalo dari Institute for Landscape Architecture and Landscape Management, Vienna di dalam Monitoring and management of visitor flows in recreational and protected areas yang berjudul "Standardisation of Visitor Counting- Experiences from Finland". Penelitian ini membahas tentang penerapan visitor counter di beberapa titik di taman nasional di Finlandia guna mengatasi masalah penghitungan pengunjung yang ada. Dalam penerapannya beberapa visitor counter dengan jenis berbeda ditempatkan dan diset sedemikian rupa menyesuaikan dengan keadaan dan kondisi yang ada guna menghasilkan data pengunjung yang tepat dengan metode yang lebih baik. Sebelumnya untuk mendapatkan data pengunjung yang tepat sangat sulit, namun dengan diterapkannya sistem ini penghitungan terhadap pengunjung dapat dilakukan dengan lebih baik, hal ini juga mengatasi permasalahan seperti banyaknya angka pengunjung tak dikenal [7].

Dari beberapa literature review di atas, dapat dilihat bahwa banyak penelitian mengenai pentingnya sebuah alat monitoring sebagai acuan pengambilan keputusan. Namun dari beberapa ulasan literature review di atas juga dapat disimpulkan bahwa hingga saat ini belum ada peneliti yang secara khusus membahas tentang penerapan Stat counter sebagai alat monitoring tingkat aktifitas website dimana dalam penelitian ini adalah website Hibah Perguruan Tinggi Raharja.

\section{HASIL DAN PEMBAHASAN}

Setelah dilakukan penelitian pada Flagcounter yang sebelumnya telah digunakan pada website Hibah Perguruan Tinggi Raharja, didapati bahwa sistem penghitungan yang diterapkan oleh Flagcounter tidak berdasarkan unique visit tetapi berdasarkan angka page-load dimana dalam hal ini setiap kali pengunjung melakukan refresh page/reload page hal itu akan menambah angka kunjungan pada visitor counter.

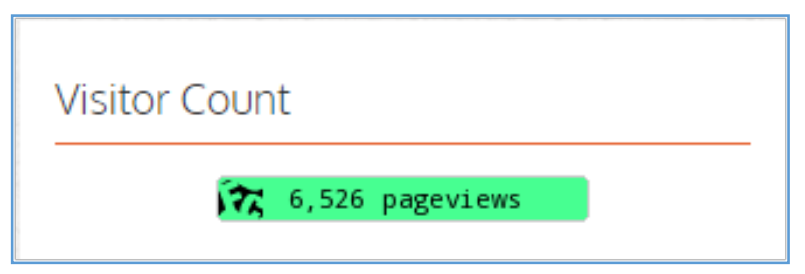

Gambar 2. Tampilan Flagcounter

Gambar 2 merupakan tampilan dari Flagcounter, dan seperti yang dapat dilihat pada gambar di atas, angka yang ditampilkan pada counter diatas adalah angka perhitungan pengunjung yang diterima Flagcounter. 


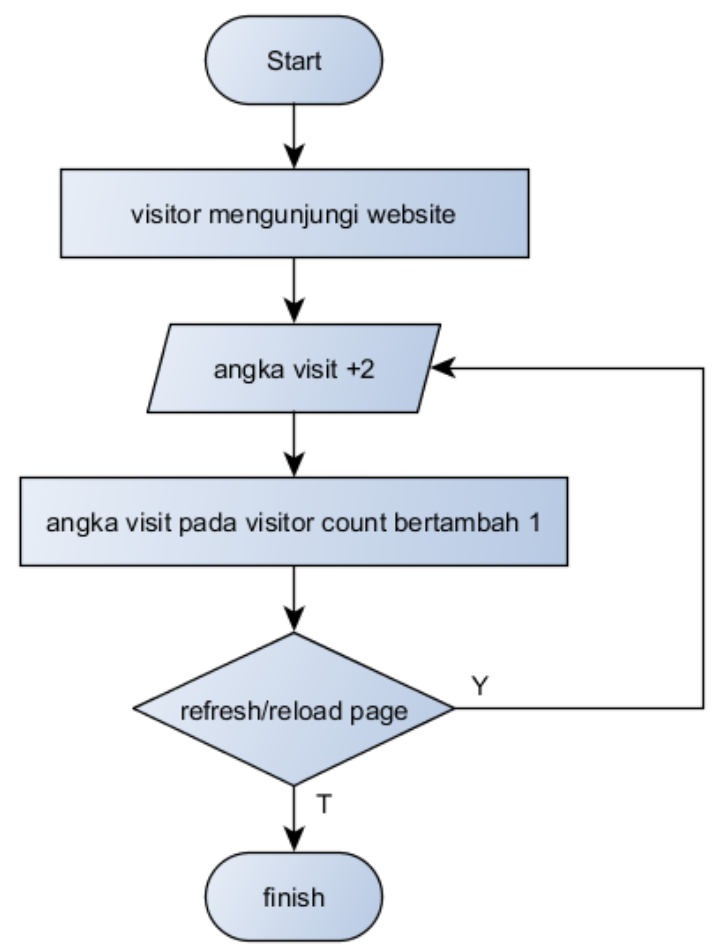

Gambar 3. Flowchart sistem perhitungan Flagcounter

Gambar 3 merupakan Flowchart sistem penghitungan pada Flagcounter. Penghitungan yang diterapkan oleh Flagcounter tidak berdasarkan uniqe visite tetapi per-pageload atau perpageview sehingga hitungannya selalu bertambah setiap kali seseorang mengunjungi suatu website atau ketika halaman web di-refresh atau dimuat ulang.

Selain itu Flagcounter bersifat fast counter. Fast counter adalah visitor count dengan hitungan hits atau hitungan kunjungannya akan dihitung pada saat seorang visitor (pengunjung) berkunjung ke website yang dimaksud, tidak peduli "sengaja berkunjung” atau tidak. Berbeda dengan sifat slow counter yang memulai hitungan setelah seorang visitor (pengunjung) berkunjung dalam kurun waktu tertentu karena mereka dianggap secara sengaja mengunjungi dan diam untuk membaca konten yang ada pada website yang dikunjungi.

Kemudian dari uraian yang telah dibahas sebelumnya, dapat ditarik suatu permasalahan yaitu kurang tepatnya penggunaan Flagcounter sebagai alat monitoring tingkat aktivitas website Hibah Perguruan Tinggi Raharja. Hal ini disebabkan sistem penghitungan yang diterapkan pada visitor count tidak berdasarkan unique visit melainkan per-pageload atau per-pageviews sehingga penghitungan tidak dapat dijadikan acuan ataupun tolak ukur tingkat aktivitas website Hibah Perguruan Tinggi Raharja.

Dan oleh karena alasan di atas, maka dirasa perlu untuk diterapkan suatu alat monitoring tingkat aktifitas website Hibah Perguruan Tinggi Raharja yang dapat menggantikan peran visitor counter yang ada saat ini. Alat monitoring yang dapat dijadikan bahan pertimbangan bagi pengelola atau admin untuk dapat mengukur tingkat aktifitas website Hibah Perguruan Tinggi Raharja, sehingga dapat dijadikan bahan acuan untuk pengelola atau admin untuk dapat meningkatkan kualitas website Perguruan Tinggi Raharja baik itu dari segi informasi maupun dari segi kualitas website Hibah Perguruan Tinggi Raharja.

Statcounter merupakan salah satu penyedia visitor counter secara gratis (statcounter.com) dengan salah satu keunggulannya yaitu dapat melakukan penghitungan atas pengunjung (visitor) berdasarkan unique visit. Dibanding dengan Flagcounter, Statcounter bisa dikatakan lebih unggul dalam hal kualitas data pengunjung karena angka visitor counter dapat diset dihitung berdasarkan unique visit. Statcounter juga menyediakan penghitungan dengan beberapa kategori yang dapat dijadikan data dan informasi yang berguna, antara lain returning 
visits, first time visits, unique visit, page view dimana unique visits berasal dari hasil penghitungan returning visit dan first time visit. Selain itu, Statcounter menyediakan email report yang dapat diset untuk dikirimkan setiap minggu, bulan, bahkan setahun sekali.

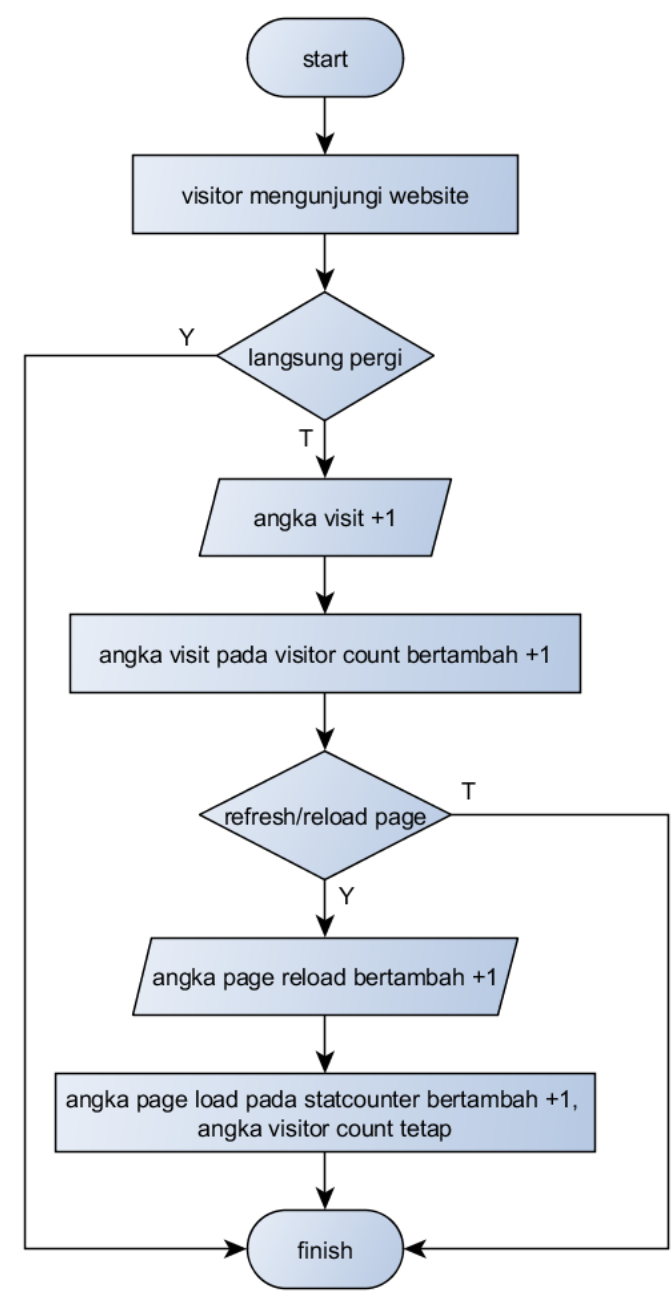

Gambar 4. Alur Flowchart Statcounter

Pada gambar 4 dapat dilihat bahwa sistem penghitungan Statcounter dilakukan dengan anggapan seorang pengunjung (visitor) adalah mereka yang benar-benar dengan "sengaja” datang berkunjung. Penghitungan pada angka pengunjung baru akan dilakukan apabila pengunjung (visitor) berdiam diri selama beberapa saat dan tidak langsung meninggalkan website. Selain itu jika pada Flagcounter mengakumulasi page load atau page refresh lalu ditampilkan pada angka visitor count, hal itu tidak dilakukan pada Statcounter. Angka page load akan diakumulasikan namun tidak ditampilkan pada tampilan visitor counter yang dipasang di website Hibah Perguruan Tinggi Raharja. Angka yang ditampilkan pada visitor counter hanyalah angka unique visit, dan data lainnya akan disimpan dan ditampilkan pada dasboard statistik website Hibah Perguruan Tinggi Raharja.

Selanjutnya setelah dilakukan implementasi secara langsung pada website Hibah Perguruan Tinggi Raharja, penerapan Statcounter sebagai alat monitoring aktivitas website dapat memberikan hasil yang lebih baik dibandingkan dengan visitor counter yang diterapkan sebelumnya (Flagcounter). Hal ini dapat dibuktikan dengan beberapa statistik yang diberikan oleh Statcounter. 


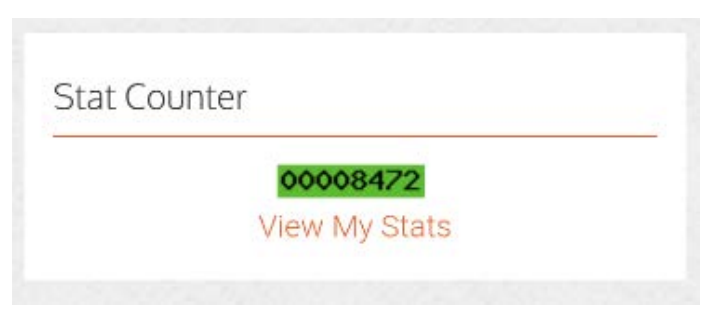

Gambar 5. Tampilan widget Statcounter

Gambar 5 merupakan tampilan dari widget Statcounter yang dipasang pada website Hibah Perguruan Tinggi Raharja. Dengan adanya widget ini pengelola dapat mengetahui secara kuantitatif jumlah pengunjung website, sebagai contoh pada Gambar 5 terlihat sebanyak 8472 pengunjung yang telah mengunjungi website Hibah Perguruan Tinggi Raharja. Angka yang diampilkan pada widget pada Gambar 5 adalah akumulasi jumlah pengunjung website secara unique visit seperti yang telah dibahas sebelumnya.

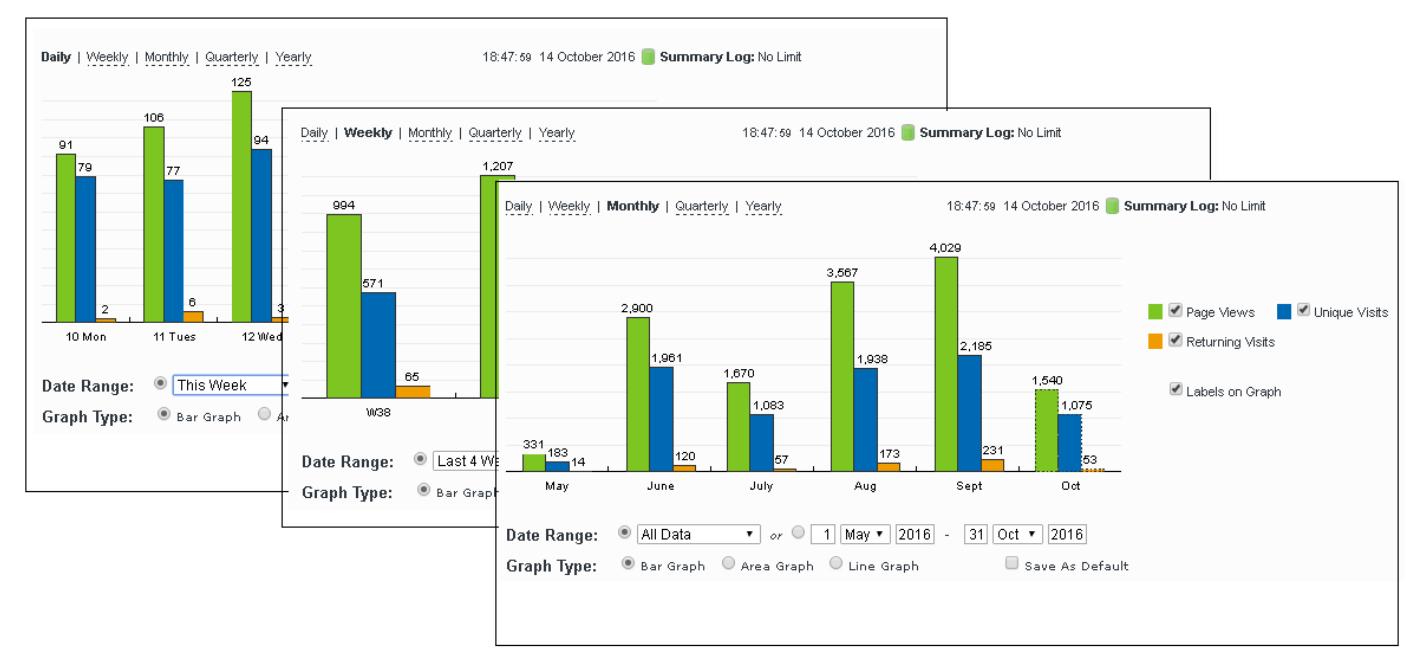

Gambar 6. Grafik Aktivitas Kunjungan Website Hibah

Gambar 6 merupakan grafik aktivitas kunjungan yang ditampilkan Statcounter yang diperoleh secara langsung selama Statcounter dipasang pada website Hibah Perguruan Tinggi Raharja. Data yang disajikan dalam bentuk grafik memudahkan bagi pengelola untuk dapat memonitoring aktivitas kunjungan website baik harian, mingguan, bulanan, pertiga bulan, maupun tahunan, sehingga pengelola dapat mengetahui secara kuantitatif apakah kunjungan pada website sedang meningkat, menurun, atau sama dengan hari, minggu, bulan, 3 bulan, tahun sebelumnya.

Grafik yang disajikan juga menampilkan aktivitas kunjungan ke dalam beberapa kategori seperti page views, unique visits, returning visits, dimana page views merupakan angka banyaknya halaman dilihat (termasuk di muat), unique visits banyaknya pengunjung unik, dan returning visits banyaknya angka pengunjung yang kembali mengunjungi website Hibah Perguruan Tinggi Raharja. 
Citec Journal, Vol. 4, No. 1, November 2016 - Januari 2017

ISSN: 2460-4259

\begin{tabular}{lrrrr} 
& Page Vews & Unique Visits & First Time Vsits & Returning Vsits \\
\hline Total & 14,037 & 8,425 & 7,777 & 648 \\
Monthly Average & 2,340 & 1,405 & 1,297 & 108 \\
& & & & \\
& Page Vews & Unique Visits & First Time Vsits & Returning Vsits \\
Oct 2016 & 1,540 & 1,075 & 1,022 & 53 \\
Sept 2016 & 4,029 & 2,185 & 1,954 & 231 \\
Aug 2016 & 3,567 & 1,938 & 1,765 & 173 \\
July 2016 & 1,670 & 1,083 & 1,026 & 57 \\
June 2016 & 2,900 & 1,961 & 1,841 & 120 \\
May 2016 & 331 & 183 & 169 & 14
\end{tabular}

Returning Visits - Based purely on a cookie, if this person is returning to your website for another visit an hour or more later

First Time Visits - Based purely on a cookie, if this person has no cookie then this is considered their first time at your website.

Unique Visits - Based purely on a cookie, this is the total of the returning visits and first time visits - a total count of visits.

Page Views - The number of times your page has been visited.

Gambar 7. Tampilan Rekap Kunjungan Website Hibah

Gambar 7 adalah rekap kunjungan yang ditampilkan Statcounter yang disajikan secara lengkap secara keseluruhan dan rekap perbulannya. Pada bagian ini pengelola dapat memonitoring secara akurat kuantitas kunjungan pada website yang jika pada grafik sebelumnya (gambar 6) dikelompokan kedalam 3 kategori. Pada bagian ini Statcounter menampilkan satu kategori tambahan yaitu first time visits yaitu banyaknya angka kunjungan pertama pada website Hibah Perguruan Tinggi Raharja. Pada gambar 7 di atas dapat diketahui bahwa mulai bulan Mei sampai dengan Oktober telah terdapat sebanyak 14.037 page views, 8.425 unique visits, 7.777 first time visits, dan 648 returning visits.

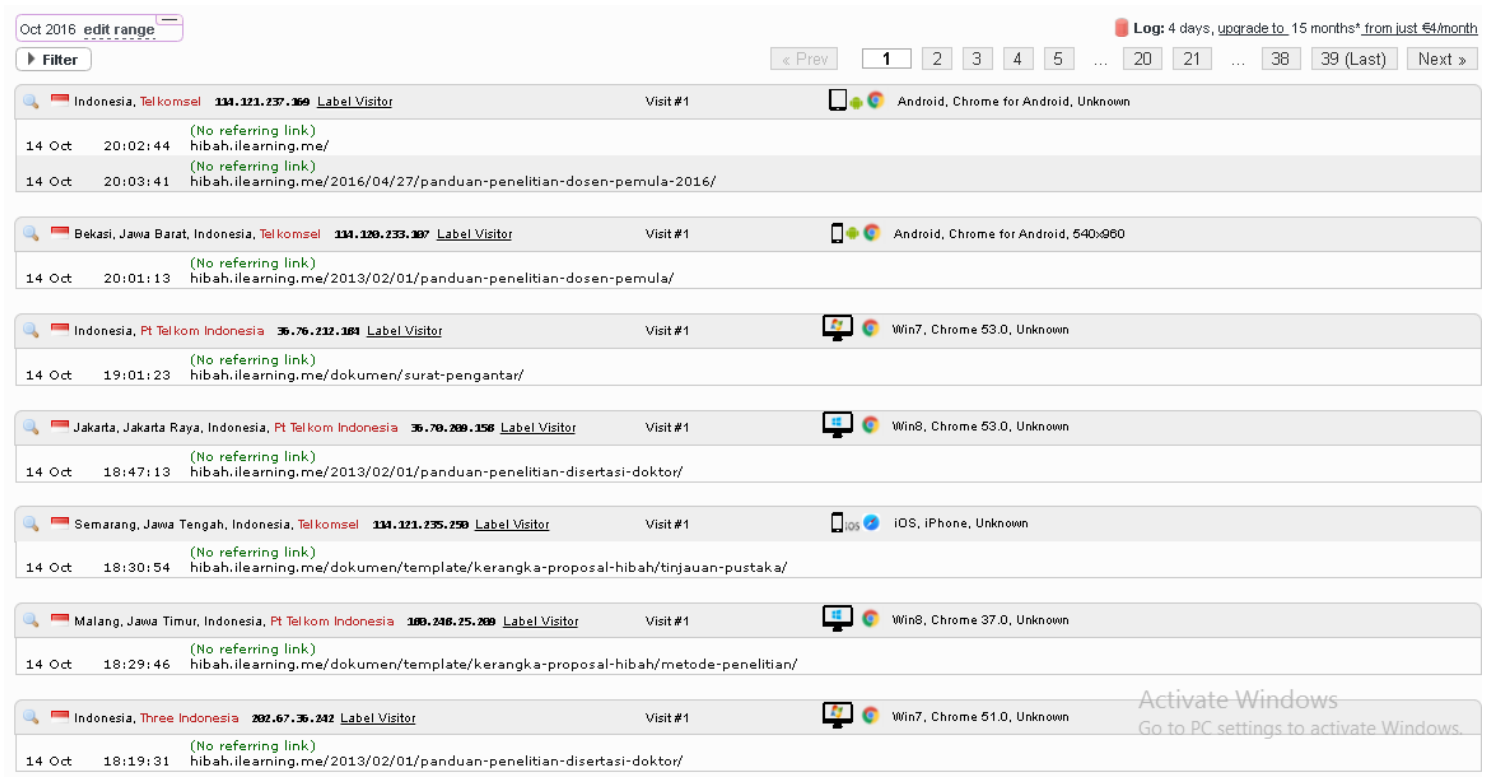

Gambar 8. Tampilan Visitor Paths 
Gambar 8 merupakan tampilan dari log history aktivitas pengunjung di website Hibah Perguruan Tinggi Raharja, pada bagian ini ditampilkan beberapa kategori seperti country, region, paths website yang dikunjungi, waktu kunjungan, serta perangkat dan browser yang digunakan. Pada bagian ini Pengelola dapat me-monitoring bagian mana saja dari website yang sering dikunjungi oleh pengunjung, kapan waktu website paling sering maupun paling sedikit dikunjungi, serta dari perangkat mana paling banyak pengunjung mengakses website Hibah Perguruan Tinggi dimana pada bagian ini fungsi penyortiran juga dapat diberlakukan sehingga Pengelola dapat memperoleh informasi sesuai dengan kebutuhannya.

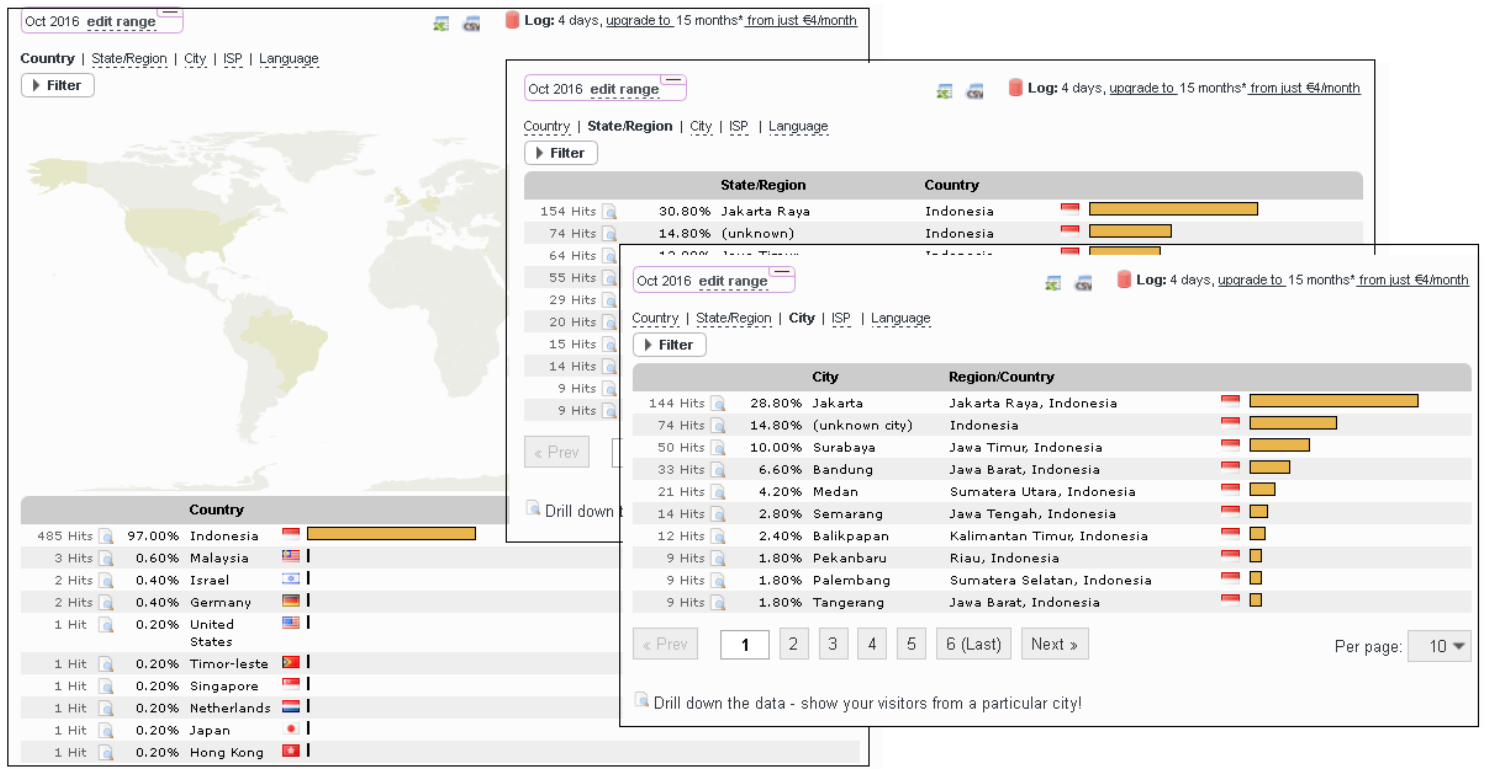

Gambar 9. Tampilan Berdasarkan Country, State/Region, dll

Gambar 9 merupakan gambaran statistik berdasarkan kategori negara, provinsi, dan kota yang disajikan Statcounter. Pada bagian ini Pengelola mendapatkan informasi perihal banyaknya Hits pada tiap-tiap kategori tersebut, dapat mengukur secara jelas tingkat aktivitas kunjungan berdasarkan banyaknya Hits pada kategori yang telah disortir berdasarkan kebutuhan. Dalam hal ini untuk website Hibah Perguruan Tinggi Raharja dapat disortir ke dalam kategori, Negara: Indonesia, State/Region: Jakarta Raya (hal ini dikarenakan pencatatan statcounter menggabungkan DKI Jakarta dan Banten ke dalam kategori tersebut), City: Jakarta/ Tangerang, dan sortiran lainnya berdasarkan kebutuhannya. 
Citec Journal, Vol. 4, No. 1, November 2016 - Januari 2017

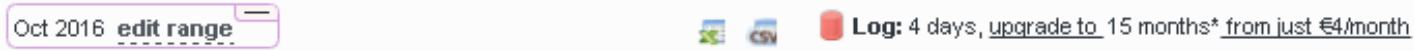

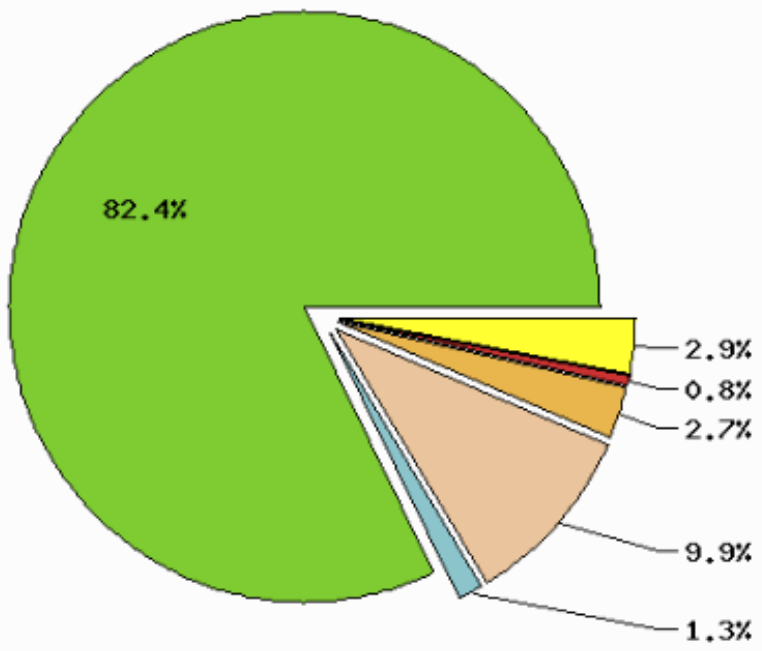

Visit Length
308 Visits $\square$ Less than 5 secs
5 Visits $\square$ From 5 secs to 30 secs
37 Visits $\square$ From 30 secs to 5 mins
10 Visits $\square$ From 5 mins to 20 mins
3 Visits $\square$ From 20 mins to an hour
11 Visits $\square$ Longer than an hour

Q Drill down the data - show the visitors with the shortest or longest visitor length.

\section{Gambar 10. Tampilan Grafik Visit Length}

Gambar 10 adalah tampilan dari grafik atas sedikit lamanya waktu kunjungan pada website Hibah Perguruan Tinggi Raharja. Pada bagian ini ditampilkan berdasarkan beberapa kategori seperti pada gambar di atas. Dengan adanya grafik ini Pengelola memonitoring dan dapat mengetahui secara akurat persentase dari lamanya kunjungan tiap pengunjung pada website Hibah Perguruan Tinggi Raharja. Pada gambar 10 dapat dilihat bahwa persentase atas kunjungan yang kurang dari 5 detik pada website Hibah Perguruan Tinggi Raharja mencapai angka 82.4\% dari total keseluruhan, dengan 2,9\% untuk kunjungan lebih dari satu jam.

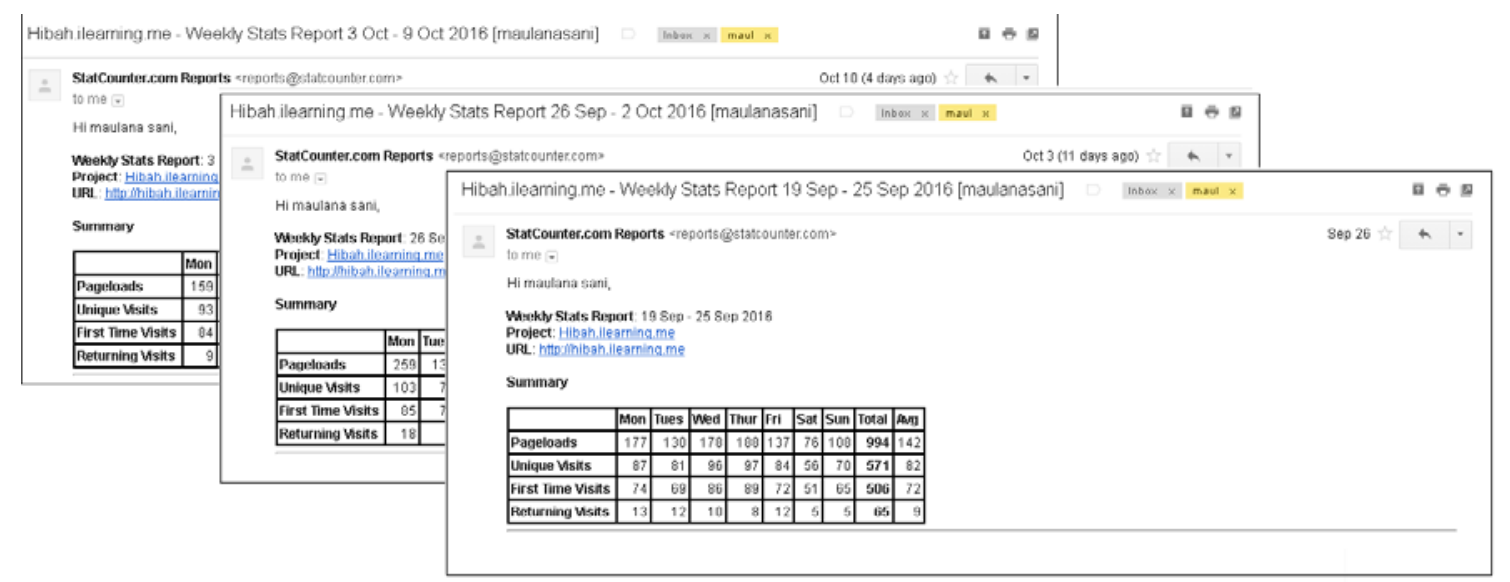

Gambar 11. Tampilan Email Report Statcounter 
Gambar 11 merupakan tampilan dari email report mingguan (dapat diset harian, mingguan atau bulanan) yang diterima Pengelola dari Statcounter secara otomatis tiap minggunya. Dengan adanya email report ini Pengelola diberikan kemudahan dalam memonitoring aktivitas website Hibah Perguruan Tinggi Raharja melalui laporan yang disajikan pada email report yang diterima.

Dengan adanya email report ini juga Pengelola dapat me-monitoring aktivitas kunjungannya tanpa harus memantau secara langsung aktivitas kunjungan website melalui dashboard Statcounter. Kemudian email report ini juga dapat berfungsi sebagai pengingat bagi Pengelola atas website Hibah ditengah-tengah kesibukan sehingga aktivitas kunjungan dapat tetap di-monitoring dengan baik oleh Pengelola.

Implementasi Statcounter sebagai alat monitoring aktivitas kunjungan pada website Hibah Perguruan Tinggi Raharja, belum dapat dikatakan sempurna dalam melakukan fungsi monitoring. Hal ini disebabkan fungsi monitoring yang dihasilkan Statcounter memiliki sebuah kekurangan yaitu belum dapat menampilkan angka aktivitas kunjungan "saat ini”. Setiap aktivitas kunjungan yang terjadi pada satu waktu tidak dapat ditampilkan pada saat itu juga, melainkan hanya dapat ditampilkan dalam bentuk rekapan dengan sortiran paling sedikit adalah today atau hari ini. Sebagai contoh misalkan pada saat ini ada sebanyak 10 orang yang sedang mengunjungi website Hibah Perguruan Tinggi Raharja, Statcounter belum dapat menampilkan angka tersebut dalam Statistik maupun laporannya, karena Statcounter tidak dapat menyajikan angka banyaknya pengunjung "saat ini”.

\section{KESIMPULAN}

Berdasarkan dari hasil dari penelitian tentang penerapan statcounter sebagai alat monitoring tingkat aktivitas kunjungan website Hibah Perguruan Tinggi Raharja, penggunaan statcounter terbukti dapat memberikan hasil yang lebih baik dibandingkan dengan visitor counter sebelumnya. Statcounter mampu menghasilkan data dan informasi jauh lebih informatif bagi Pengelola. Informatif dalam artian data dan informasi yang dihasilkan sangat besar nilai gunanya bagi Pengelola dalam me-monitoring website Hibah Perguruan Tinggi Raharja yang jika dipertimbangkan kembali juga dapat dijadikan bahan pertimbangan untuk kedepannya apakah website Hibah Perguruan Tinggi Raharja harus ditingkatkan atau tidak? dan jika harus, bagian mana yang harus diubah?, dalam hal ini informasi yang diberikan stat counter juga dapat membantu pengelola atau admin untuk menjawab pertanyaan seperti berapa banyak pengunjung website minggu ini? Apakah meningkat atau menurun atau bahkan sama dengan minggu lalu?

Selain itu penggunaan Statcounter dalam hal memonitoring kunjungan pada website Hibah Perguruan Tinggi Raharja terbukti lebih baik dibanding dengan visitor counter sebelumnya. Hal ini dibuktikan dengan adanya statistik dan rincian aktivitas yang dilakukan pengunjung (visitor) yang disajikan secara kuantitatif baik berupa grafik, laporan keseluruhan, dan juga persentase.

Kemudian dengan diterapkannya Statcounter pada website Hibah Perguruan Tinggi Raharja, tentunya akan memberikan beberapa keuntungan dalam penerapannya. Adapun keuntungan yang didapatkan dengan diterapkannya Statcounter ini adalah sebagai berikut:

1. Data dan informasi yang didapatkan dari statcounter jauh lebih informatif dibandingan visitor counter sebelumnya dimana dengan Statcounter proses monitoring aktivitas website Hibah Perguruan Tinggi Raharja dapat lebih mudah dilakukan.

2. Data dan informasi yang dihasilkan statcounter dapat dijadikan bahan pertimbangan untuk pengembangan atau peningkatan website Hibah Perguruan Tinggi Raharja.

3. Proses monitoring atas aktifitas website dapat dilakukan dengan lebih baik dan terarah, serta proses dokumentasi berjalan dengan baik.

4. Adanya fitur email report yang disediakan Statcounter memudahkan Pengelola menyaksikan perkembangan website Hibah Perguruan Tinggi Raharja 
Kemudian selain kelebihan yang diberikan penerapan Statcounter sebagai alat monitoring aktivitas website Hibah Perguruan Tinggi Raharja juga masih memiliki sebuah kekurangan yaitu Statcounter belum dapat menampilkan angka monitoring atas aktivitas kunjungan "saat ini" sehingga Pengelola belum dapat mengetahui jumlah pengunjung "saat ini” secara tepat.

\section{SARAN}

Penggunaan Statcounter sebagai alat monitoring aktivitas website Hibah Perguruan Tinggi Raharja adalah suatu langkah yang cukup baik. Namun pada penerapannya pengembangan dan peningkatan atas alat monitoring aktivitas kunjungan website masih dapat dilakukan. Banyak pengembangan dan peningkatan yang dapat dilakukan untuk menghasilkan sebuah alat monitoring yang lebih baik, untuk dapat meningkatkan kualitas monitoring terhadap aktivitas kunjungan website Hibah Perguruan Tinggi Raharja. Pengelola dapat menambahkan alat monitoring lain yang dapat memenuhi kekurangan yang ada pada Statcounter yaitu perihal menampilkan angka monitoring terhadap kunjungan "saat ini", sebagai contoh google analytic misalnya.

\section{DAFTAR PUSTAKA}

[1] Yuhefizar, dkk. 2009, Cara Mudah Membangun Website interaktif Menggunakan Content Management System Joomla Edisi Revisi, Jakarta, Elex Media Komputindo.

[2] Yadanur, A.., Suhartono., Sasongko, P. S., 2012, Pengembangan Sistem Informasi Administrasi Pemeriksaan Pasien di Instalasi Radiologi Rsud Kajen dengan Unified Process, Jurnal Masyarakat Informatika, Vol. 2, No. 4, Hal. 27-36.

[3] Amalia, I., Karmilasari, 2011, Analisis Kepopuleran Website UKM dengan Metode Survey dan Perangkat Bantu Seo dan Trace Visitor. Proceeding PESAT (Psikologi, Ekonomi, Sastra, Arsitektur \& Sipil) Univ. Gunadharma, Depok, 18 - 19 Oktober.

[4] Ross, J., 2005, Visitor Counters in Parks: Management Practice for Counter Calibration. Department of Conservation, $\quad \underline{h t t p: / / w w w . d o c . g o v t . n z / d o c u m e n t s / s c i e n c e-a n d-}$ technical/docts33.pdf, diakses pada tanggal 1 Desember 2016.

[5] Cessford, G., Cockburn, S., Douglas, M., 2002, Developing New Visitor Counters and Their Applications for Management. Monitoring and Management of Visitor Flows in Recreational and Protected Areas, Vienna, 30 Januari - 02 Februari 2002.

[6] Waradkar, G., Ramina, H., Maitry, V., Ansurkar, T., Rawat, A., Das, P., 2016, Automated Room Light Controller with Visitor Counter, Imperial Journal of Interdisciplinary Research, Vol 2, No 4, Hal. 777-780.

[7] Rauhala, J., Erkkonen, J., \& Iisalo, H. (2002, January). Standardisation of visitor countingExperiences from Finland. In Monitoring and management of visitor flows in recreational and protected areas. Conference proceedings (pp. 258-263). Institute for Landscape Architecture and Landscape Management, Vienna. 